\title{
7 \\ NEW MEN AND A NEW MODEL
}

Sir George Harvie-Watt and his deputy, Gilbert Potier, with the involvement of other directors, were instrumental in establishing the basis for Consolidated Gold Fields' expansion into Australia. In this task they were ably assisted by Gerald Mortimer, a senior London-based manager, trained as a mining engineer and having held operational roles in South Africa. He later became deputy chairman and managing director. These early efforts were later supplemented by Brian Massy-Greene and his management team in Australia.

Consolidated Gold Fields (Australia) (CGFA) established a mining-finance house model, with direct investments in a range of listed companies. With one exception, there was no direct involvement in the establishment and operation of new or existing mining operations. The exception was iron ore production in the Pilbara, in Western Australia, where Mortimer was responsible for securing London board support for what was a major investment in a large, new mineral development province in the 1960s. In this case, there was an involvement by two other companies: Cyprus Mines Corporation and Utah Construction \& Mining. The presence of CGFA local management experienced in the operation of mining ventures was limited and did not develop in any meaningful sense until the 1970s. It was not until 1981, when Renison Goldfields Consolidated was created, that the company for the first time had direct ownership and operation of the main parts of its portfolio and with it a need to deploy both technical and managerial capabilities, in addition to finance, for the establishment and operation of mining and other ventures. 
The approach to acquiring a majority shareholding in a company, as opposed to outright ownership, reflected the deliberate choice made by CGFA in establishing its position in Australia. As Sidney Segal observed in 1966:

This was the initiation of a technique new to Australia whereby an outside company did not seek to acquire all the shares of a company and so preserved its Australian flavour, and fostered a partnership element between the original Australian investor and the new arrival. ${ }^{1}$

This approach was instrumental in allowing the British company to establish a presence in a range of minerals sectors, including iron ore, mineral sands, copper, tin and coal, as well as diversifying into manufacturing, property development and agricultural interests. The business model reflected the circumstances of the company: its local management presence was limited, while in the burgeoning minerals development environment of the 1960s the establishment of shareholdings, as opposed to direct control of operational mines, was an effective way to gain a foothold in the Australian mining industry. An investment in two manufacturing ventures reflected a propensity for diversification prevalent at the time, as well as a desire to reduce exposure to gold across the Gold Fields group and an attempt to dampen the cyclicality of its mineral investments.

Despite the initial inherent advantages of the CGFA business model, shortcomings and constraints became evident in the late 1960s and early 1970s. Then a combination of the decline in the financial contribution of some key investments, notably iron ore, and the inability to control the cash flows of its other investments, led to a fundamental reconsideration of the business model. It also led to management change at CGFA, with Massy-Greene replaced in 1976 as managing director at the initiative of the London shareholder. Bartholomew C (Bart) Ryan, an experienced Australian mining engineer, was appointed managing director in Australia. ${ }^{2}$ He brought both a greater degree of mining and operational experience than his predecessor and, from his posting in London as a director, an appreciation of the capital deployment and dividend considerations of Gold Fields in the context of its wider geographical business interests. Aided by Segal, who assumed the chairmanship, these two individuals and the other directors, which by the early 1970s included Sir Ian Potter,

1 'Notes on Redraft of Chapters XXV and XXVI of "History of Gold Fields"', 2 March 1966, Renison Goldfields Consolidated Archives (RGCA), Box 1091.

2 See Appendix 3 for a biographical profile of Bart Ryan. 
John Darling and Sir Daniel McVey, had developed a new business model and structure for the company. ${ }^{3}$ This process resulted in the divestment of the company's position in iron ore in 1976, consideration to the sale of its mineral sands interests - or at least some form of rationalisation of the company's Australian position in this sector-and the questioning of the efficacy of the diversified business structure.

Fundamental portfolio alternatives were considered, not least the divestment of all if not most investments, with the retention only of Renison. The inability to implement such a radical portfolio restructuring was due in large part to market constraints. Instead, CGFA emerged from the 1970s with a modification of its portfolio, including a number of the investments made in the 1960s, and with greater disciplines imposed on subsidiaries, yet with the same basic diversified portfolio structure intact. The change to the business structure to address the inherent inefficiencies that emerged from the 1960s quasi-mining-finance house model resulted in a move to a divisional structure, where the underlying businesses became wholly owned by the Australian holding company. The implementation of this 'naturalisation' process was overseen by a newly appointed chairman in 1980, MJ (Max) Roberts, although much of the foundation work had commenced earlier.

The initial investment made by CGFA was in a stock exchange-listed company, Commonwealth Mining Investments (Australia) (CMI), established in 1955. When Harvie-Watt visited Australia in January and February 1960, he had requested Frank Beggs to draw up a list of companies he thought might benefit from an investment or injection of funds. Harvie-Watt recalled sitting in his shirt sleeves with Beggs in his hotel suite in Sydney:

3 Sir Ian Potter, a Melbourne stockbroker, company adviser and philanthropist, established the firm Ian Potter \& Co. In 1970, Potter was a director of over 12 Australian companies, including Boral, McIlwraith McEacharn and Email. John Darling was a businessman and company director of Alcoa of Australia; Austran; British Petroleum; Commonwealth Mining Investments; Monsanto Australia; Sims Consolidated; and Schroder, Darling and Company Holdings. Sir Daniel McVey served as director-general of Posts and Telegraphs from December 1939 and director of War Organization of Industry from November 1941. From February 1944 he held the post of directorgeneral of Civil Aviation. He resigned from the public service in 1946 to enter private industry and served as chairman and managing director of Standard Telephones \& Cables (Australia), managing director of Metal Manufactures and Austral Bronze Co. and held managerial and directorial roles at Dunlop Rubber Australia, as well as directorships of Amalgamated Wireless (Australasia), Bellambi Coal Company and McIlwraith McEacharn. 
It was gruelling hot with no air conditioning. He [Beggs] kept on showing me details of very large companies and I said we must aim our sights a lot lower ... I picked up papers relating to a much smaller company ... It was the dossier of Commonwealth Mining. It was just the right size and what I had been thinking of all along. I asked him if he knew the people involved. ${ }^{4}$

The company that attracted Harvie-Watt, and which was reviewed in detail in London, held a spread of investments in most of the main mining companies in Australia at the time. It mirrored, in some respects, the earlier model of Gold Fields investing in Australia with an association with financiers, entrepreneurs and mining men.

CMI was established, in part, due to the absence in Australia in the 1950s of mining-finance companies that, in other countries, were viewed as playing 'a vital part in the development of the mining industry of those countries'. 5 Its charter was to invest in selected mining companies, assist with new flotations, underwrite share issues and advance loan funds. Charles Ord of the stockbroking firm Ord \& Minnett played a key role in the establishment of the company. Ord encouraged a number of leading mining professionals to join the board. Its initial investments included Broken Hill South, North Broken Hill, Mount Isa Mines, Mount Morgan and Gold Mines of Kalgoorlie, as well as a holding in companies that were or would form part of the CGFA portfolio: Lake View and Star, Mount Lyell Mining and Railway Company, and Western Titanium.

Harvie-Watt observed a depth of mining experience within CMI, as well as existing professional connections. Julius Kruttschnitt, the chairman, had been general manager and chairman of Mount Isa Mines and also a director and chairman for over 30 years of New Guinea Goldfields, the company in which Consolidated Gold Fields had invested. ${ }^{6}$ Keith Cameron, the managing director, had worked for the WS Robinsonsponsored Gold Mines of Australia, a company within the Collins House Group of mining companies. He had worked at Mount Lyell Mining and Railway Company, as well as being a director of New Consolidated Goldfields' more recent investment in Mining Corporation (Australia). He had also worked at North Broken Hill and was managing director of Mount Morgan. Another director, AHP Moline, had been chairman

4 Harvie-Watt, Most of My Life, p. 251.

5 Commonwealth Mining Investments (Australia) Limited, 'Prospectus', University of Melbourne Archives (UMA), Stock Exchange of Melbourne, 1968.0018, Box 65.

6 Hopper and Lynch, 'Kruttschnitt, Julius (1885-1974)'. 
of Mount Kathleen Uranium, as well as general manager of Mount Lyell Mining and Railway Company. ${ }^{7}$ Added to these attributes, CMI had sponsored the listing in its own right of a number of companies, including two mineral sands companies-Wyong Minerals and Western Titanium. Harvie-Watt and Mortimer were both attracted to mineral sands as a sector for investment and CMI had a foothold in a number of companies operating on both the east and west coast of the country.

CMI became, in effect, the 'eyes and ears' for Consolidated Gold Fields in Australia in its early days. ${ }^{8}$ It also became the progenitor of CGFA's broad involvement in mineral sands, as well as the identification of other companies, such as Mount Lyell and Renison, that became key parts of the portfolio. It led to the identification of companies, including King Island Scheelite and North Broken Hill, that were viewed as appropriate investment opportunities.

The Consolidated Goldfields of South Africa made a proposal through its directors Gilbert Potier and Donald McCall to subscribe for an issue of 3.5 million stock units in CMI in July 1960. The board of CMI considered the proposal and it was declined. Cameron, as managing director, visited London and met the directors of Gold Fields. At his request, the proposal was reconsidered. Yet again the arrangement was declined by his fellow directors. On 4 August 1960 the matter was considered a third time by the CMI board at the behest of Cameron. This time, 'after lengthy discussion it was resolved that the offer be accepted in principle.?

At the first board meeting of CGFA on 9 November 1960, the application for 3.5 million shares in CMI was authorised. CGFA acquired a 54 per cent shareholding and additional shares were purchased the following year. Four CGFA directors were nominated to the board of CMI. ${ }^{10}$ In turn, Cameron became a director of New Consolidated Gold Fields (Australasia) and an inaugural director of CGFA in 1960, as well as being employed as a technical officer of the company.

7 Moline was general manager of Mount Lyell for four years, 1944-1948 ('Historical Notes of AHP Moline (1877-1965) (Written circa 1961/1962)', State Library of Victoria, MS 10883).

$8 \quad$ I am indebted to Ted Wiles for his recollections of this period.

9 Commonwealth Mining Investments (Australia) Limited, 'Board Minutes', 21 July 1960, 4 August 1960, 10 November 1960, UMA, Commonwealth Mining Investments (Australia) Limited Board Minute Books, 1955-1979, 2012.0202.

10 The initial directors were Harvie-Watt, Potier, Beggs and Gabriel Selmar Reichenbach (Consolidated Gold Fields (Australia) Pty Limited, 'Minutes of Meeting of Directors of Consolidated Gold Fields (Australia) Pty Limited', 13 January 1961, p. 8, RGCA, Box 12264). 
The advantage to CMI was that the issuance of shares improved the capital structure of the company and established a relationship with a major mining house with net assets of GBP£46 million. In Australia it provided an association that enabled it to continue to invest, as well as be able to participate in exploration prospecting activities through its association with New Consolidated Gold Fields (Australasia), quite apart from the benefits of 'access to world-wide resources: financial, technical and marketing' provided by Consolidated Gold Fields. ${ }^{11}$ CMI was viewed as a mining-finance company with a well-spread portfolio of mining investments in Australia. Significantly, the offshoot of the British mining and finance house, with deep roots in South Africa, had gained a controlling position in an Australian entity that had an involvement in a mineral sector it had known virtually nothing about-mineral sands - as well as an ability to assess a range of other mining investment opportunities in the country.

At Potier's suggestion, $A £ 1$ million of the investment in the company was held overseas to enable investment in international mining companies. Consolidated Gold Fields and CMI were able to come to an arrangement with the Commonwealth Treasury whereby they could overcome the investment restrictions then in place, enabling CMI to establish a portfolio that included a spread of both international and Australian investments. ${ }^{12}$ In this manner, the company drew upon the expertise of Consolidated Gold Fields' London investment department to broaden its portfolio of investments, both geographically and with the inclusion of industrial companies.

In 1962, Cameron proposed a series of arrangements to his board. CGFA was appointed as investment manager to CMI and the company ceased to incur direct expenditure for prospects or new projects. Instead, this expenditure was incurred by CGFA; the staffing of CMI was also provided by personnel from the company. As such, the company became responsible for the investment portfolio of CMI. CGFA generated a management fee and gained a perspective of investment opportunities across the minerals sector in Australia. Douglas Ainge, an employee of CGFA, became investment manager. Ted Wiles was appointed assistant

11 Commonwealth Mining Investments (Australia) Limited, 'Circular to Shareholders', 26 September 1960, UMA, Stock Exchange of Melbourne, 1968.0018, Box 65.

12 By June 1961, the portfolio had a spread of Australian-listed and overseas-listed mining companies, including Anaconda Company, Cyprus Mines Corporation, Kennecott Copper Corporation, Phelps Dodge Corporation and Falconbridge Nickel. 
investment manager and head of the valuation department, reporting to Ainge. On the CMI management committee were Massy-Greene, Ainge, Wiles and Michael Gleeson-White (a director and also partner of Ord \& Minnett, and later chief executive officer of Schroders Australia). The committee met monthly to provide investment recommendations to the CMI board. CMI occupied offices at Gold Fields House from 1966.

The most notable activity undertaken by CMI that directly influenced the portfolio of CGFA was its involvement in mineral sands. CMI sponsored the share market listing of Wyong Minerals in 1959 with Cameron serving as initial chairman. The predecessor company, Wyong Alluvial, held leases adjacent to Lake Munmorah in New South Wales, which it proposed to develop in the new company through a dredge-mining operation. A shareholding in another east-coast mineral sands producer, Eastern Titanium Corporation, was established, as well as arrangements with two other mineral sands producers for the supply of rutile.

CGFA gained its main involvement in mineral sands through acquiring shares in another east-coast producer, Associated Minerals Consolidated, while also having a shareholding in Wyong Minerals. In 1967, CGFA facilitated a merger of Associated Minerals Consolidated and Wyong Minerals as the first stage of an expanded presence in the mineral sands industry in Australia. It later acquired another CMI-sponsored mineral sands company-Western Titanium — and in so doing established itself as the largest Australian and global producer of rutile, ilmenite and zircon, with mineral sands becoming a major part of its overall portfolio of investments.

Over a seven-year period after CGFA acquired its majority holding in CMI to 30 June 1968, the book value of CMI's investments rose from $\mathrm{A} \$ 5,692,000$ to $\mathrm{A} \$ 10,971,000$ and annual dividends increased from five cents to 11 cents a share. CMI proved to be a successful investment on a number of fronts, although one that created potential conflicts of interests for directors given the broadening of CGFA's own portfolio to include investments in companies in which CMI had also invested. CGFA maintained an investment in CMI until 1978, when its 60.17 per cent interest was sold to National Mutual Life Corporation. With the foundation investment in CMI in 1960, CGFA moved to broaden its business presence in Australia. 
This text is taken from Consolidated Gold Fields in Australia: The Rise and Decline of a British Mining House, 1926-1998, by Robert Porter, published 2020 by ANU Press, The Australian National University,

Canberra, Australia.

doi.org/10.22459/CGFA.2020.07 